\title{
UNITY IN DIVERSITY: RESPON GEREJA SUARA KEBENARAN INJIL DI KOTA MEDAN DALAM MERAWAT KEMAJEMUKAN
}

\author{
Rinto F. Sirait \\ Sekolah Tinggi Teologi Siloam Medan, Indonesia \\ E-mail: siraitrinto778@gmail.com
}

Diterima tanggal: 23 Desember 2021

Dipublikasikan tanggal: 28 Desember 2021

\begin{abstract}
ABSTRAK
Artikel ini bertujuan untuk mengetahui peran gereja (secara khusus Gereja Suara Kebenaran Injil) dalam merawat kemajemukan di Indonesia. Kemajemukan merupakan karunia Tuhan bagi bangsa Indonesia. Namun demikian kemajemukan yang ada di Indonesia, khususnya kemajemukan agama banyak mengalami ujian. Pemahaman yang kurang tepat oleh sekelompok orang telah melahirkan tindakan-tindakan intoleran yang menciderai kemajemukan yang disepakati bersama oleh para pendiri bangsa Indonesia. Dengan menggunakan metode penelitian kualitatif dengan pendekatan studi eksplorasi maka penelitian ini memberikan sumbangan pengetahuan tentang respon Gereja Suara Kebenaran Injil di Kota Medan dalam usaha merawat kemajemukan di Indonesia, di antaranya adalah membangun kerja sama antar agama dengan semua komponen masyarakat dalam mewujudkan masyarakat adil dan makmur, memiliki sikap toleransi akan perbedaan-perbedaan di tengah masyarakat, dan gereja tidak boleh reaktif terhadap tindak-tindakan intoleransi; justru harus menunjukkan kasih dalam perbuatan. Gereja menginiasiasi dialog lintas agama untuk mengatasi kebuntuan dalam kemajemukan agama.
\end{abstract}

Kata kunci: pluralisme; gereja; intoleransi; kemajemukan; unity in diversity

\begin{abstract}
This article aims to determine the role of the church (specifically Gereja Suara Kebenaran Injil) in caring for pluralism in Indonesia. Pluralism is a gift from God to the Indonesian people. However, pluralism in Indonesia, especially religious pluralism, has been tested. An inaccurate understanding by a group of people has given rise to intolerant actions that injure pluralism which were mutually agreed upon by the founders of the Indonesian nation. By using qualitative research methods with an exploratory study approach, this research contributes knowledge about the response of Gereja Suara Kebenaran Injil in Medan City in an effort to care for pluralism in Indonesia, including building inter-religious cooperation with all components of society in realizing a just and prosperous society, have an attitude of tolerance for differences in society, and the church should not be reactive to acts of intolerance; Instead, you have to show love in action. The church initiated interfaith dialogue to overcome deadlocks in religious pluralism.
\end{abstract}

Keywords: pluralism, church, intolerance, plurality; unity in diversity 


\section{PENDAHULUAN}

Indonesia merupakan negara yang majemuk dengan beragam suku, agama, ras dan golongan. Undang-Undang mengakui ada 6 agama di Indonesia di antaranya: Islam, Kristen, Katolik, Hindu, Budha dan Kong $\mathrm{Hu} \mathrm{Cu}$ ditambah dengan penghayat aliran kepercayaan lainnya. Keenam agama yang berbeda ini hidup nyaman berdampingan satu dengan yang lain. Bekerja sama merebut kemerdekaan dari tangan penjajah, bekerja sama dalam mengisi kemerdekaan dan dalam memajukan bangsa. Sikap kebersamaan yang demikian terjalin dengan baik untuk waktu yang cukup lama. Sampai suatu waktu, sikap intoleransi jamak dipertontonkan belakangan ini. Di mana sekelompok orang mencoba membenturkan sesama anak bangsa dengan benturanbenturan agama, suku, ras, dan golongan. Di antara perbedaan tersebut, benturan agama dan keyakinan paling menonjol dalam merusak kemajemukan yang terus di rajut di tengah-tengah bangsa Indonesia.

Hasil penelitian setara institute yang dirilis bulan April 2021 mencatat bahwa ada 422 tindakan pelanggaran kebebasan beragama selama tahun 2020. Dari jumlah tersebut ada 184 tindakan yang dilakukan oleh aktor non negara seperti sekelompok warga, individu, organisasi kemasyarakatan (ormas), dan ormas keagamaan. Di antaranya pelanggaran kebebasan beragama 62 tindakan, penodaan agama 32 tindakan, 17 tindakan penolakan mendirikan tempat ibadah, 8 tindakan pelarangan aktivitas ibadah, 6 tindakan perusakan tempat ibadah, serta kekerasan dan penolakan kegiatan lainnya masing-masing 5 tindakan (Lidwina, 2021).

Di samping itu sekelompok politisi mencoba memainkan isu intoleransi untuk merebut simpati golongan tertentu sebagaimana terjadi dalam pemilihan gubernur di Provinsi DKI Jakarta (Lestari, 2019). Sejatinya pembenturan seperti ini merupakan langkah picik dan sadis untuk merebut simpati masyarakat dan di saat yang sama menumbalkan fondasi kemajemukan bangsa. Aziz (2017) berkata jika ada kelompok politik dan (calon) pemimpin yang menggunakan kemajemukan sebagai alat untuk memecah belah bangsa, hal ini merupakan politik kebencian yang berbahaya. Prinsipprinsip kemajemukan bangsa dirusak oleh kepentingan politik yang menggunakan jubah agama. Narasi kemajemukan ditikam oleh gerakan Islamisme, yang mengambil manfaat dari sentimen agama seraya memompa kebencian dari penganut agama yang lain. 
Dengan demikian hubungan Islam dan non-Islam telah demikian mengeras dan meruncing perbedaannya, dari yang sebelumnya sebagai saudara dalam bingkai Negara Kesatuan Republik Indonesia (Aziz, 2017).

Di kota Medan Sumatera Utara sendiri kerap terjadi beberapa tindakan intoleransi, contohnya: penghadangan jemaat dalam beribadah (Batubara, 2019), pembakaran dan penjarahan delapan Vihara di Tanjung Balai (Siswoyo \& Nasution, 2016), aksi protes pendirian tempat ibadah (Utomo, 2019), dan Tindakan intoleransi lainnya. Sekelompok orang di dalam gereja yang merasa terusik dengan kehadiran kelompok intoleran ini pun seolah berusaha untuk memberikan perlawanan dengan menyerang ajaran yang dipahami oleh penganut agama lain. Sebagai contohnya; beberapa bulan belakangan ini muncul Jozeph Paul Zhang dalam kanal youtube nya diduga melakukan penghinaan terhadap umat Islam (Putranto, 2021). Muhammad Kace dengan lima pernyataannya yang sangat menyakitkan bagi umat Islam, diantaranya menyebutkan Nabi Muhamad sebagai pengikut jin, kitab kuning menyesatkan, menyelewengkan salam, mengajak untuk meninggalkan ajaran Nabi Muhammad SAW karena tidak dapat menyelamatkan umat Islam, dan terakhir menyebutkan ajaran Nabi Muhammad hanyalah mitos (Muslim, 2021). Kehadiran orang-orang ini pada akhirnya mendapat kecaman dari banyak orang dan memperparah friksi yang sudah ada. Sebenarnya jika ditelusuri lebih lanjut maka paham-paham intoleransi seperti ini diakibatkan dangkalnya pemahaman akan agama yang dianutnya dan rendahnya tingkat spritualitas. Novalina (2020) berpendapat bahwa spiritualitas seseorang dalam beragama seharusnya diekspresikan dalam tindakan yang konstruktif. Di tengah pluralitas masyarakat Indonesia, Gereja seharusnya hadir memberikan keteduhan bagi masyarakat yang plural bukan sebaliknya menimbulkan kegaduhan (Novalina, 2020).

Dalam menghadapi ujian dan tantangan kemajemukan yang terjadi maka masyarakat harus diingatkan tentang sejarah keberagaman di Indonesia, jati diri sebagai anak bangsa dan identitas kebangsaan yang dimiliki. Hal ini senada dengan apa yang disampaikan oleh Suhardi Alius dalam Erlangga bahwa bangsa Indonesia tidak hanya memerlukan ikatan tetapi juga ingatan akan sejarah, jati diri dan karakter masyarakat (Erlangga, 2017). Sukarno dalam sebuah pidatonya berkata, "jika ingin menjadi orang Islam, jangan menjadi orang Arab. Jika ingin menjadi orang Hindu, jangan menjadi orang India. Jika ingin menjadi orang Kristen, jangan menjadi orang Yahudi.” Seperti 
yang disampaikan oleh Soegiapranata, 100 persen Katolik sekaligus 100 persen Pancasilais atau nasionalis (Cipta, 2020). Itu berarti Gereja harus memiliki pengertian dan pemahaman yang kuat dan kokoh akan iman Kristen, namun di saat yang sama harus menjadi bagian anak bangsa yang menghargai kemajemukan.

Beberapa penelitian sebelumnya yang berhubungan dengan kemajemukan diantaranya Piter dan Titaley (2014) mengambil fokus pada hubungan antar agama. Hasil penelitiannya memaparkan hubungan yang toleran antara jemaat GPIB Tamansari dengan masyarakat muslim di Dusun Kalimangi (Pieter \& Titaley, 2014). Aritonang (2019) lebih membahas masalah peran sosiologis gereja dalam relasi kehidupan antar umat beragama di Indonesia. Hasil penelitiannya menekankan pentingnya sikap inklusif gereja, peran gereja dalam setiap persoalan bangsa (Aritonang, 2019). Peter (2020) dalam kajiannya menekankan pentingnya pendidikan agama Kristen dalam membangun wawasan kebangsaan bagi para peserta didik dalam menghadapi isu toleransi dan radikalisme di Indonesia. Peserta didik harus memiliki sikap nasionalisme dan tidak terpapar tindakan-tindakan yang dapat mengganggu tatanan kehidupan berbangsa dan bernegara (Peter, 2020). Berdasarkan penelitian-penelitian terdahulu masih terdapat gap dimana penulis belum menemukan peran gereja secara khusus gereja dari sinode Gereja Suara Kebenaran Injil dalam merawat kemajemukan di Negara Kesatuan Republik Indonesia.

Penelitian ini bertujuan untuk mengetahui: Bagaimana Gereja Suara Kebenaran Injil di kota Medan menghadapi kemajemukan di Indonesia? Apa peran Gereja Suara Kebenaran Injil di kota Medan dalam merawat kemajemukan di Indonesia? Bagaimana mewujudkan peran tersebut? Apa tantangan yang dihadapi Gereja Suara Kebenaran Injil dalam menjaga kemajemukan dalam bingkai Negara Kesatuan Republik Indonesia?

\section{METODE}

Pembahasan dalam artikel ini menggunakan metode penelitian kualitatif dengan pendekatan studi eksplorasi terhadap sumber-sumber primer. Berdasarkan sifat penelitiannya, pendekatan kualitatif lebih mengarah pada penyelidikan kebenaran yang bersifat relatif, hermeneutik dan interpretatif. Studi Eskplorasi dilakukan untuk mengetahui atau meningkatkan pemahaman (Zaluchu, 2020) peneliti tentang respon Gereja Suara Kebenaran Injil di Kota Medan terhadap fenomena kemajemukan yang 
terjadi di Indonesia. Itulah mengapa, hasil jawaban dari angket yang diberikan peneliti kepada pendeta-pendeta dari Gereja Suara Kebenaran Injil di Kota Medan pada bulan Oktober - Nopember 2021 dianalisis dan dijadikan topik-topik yang dirangkai menjadi sub bab dalam pembahasan artikel ini. Adapun beberapa pertanyaan yang diajukan adalah: (1) Apa yang bapak/ ibu pahami tentang kemajemukan dalam bingkai Negara Kesatuan Republik Indonesia? (2) Menurut bapak/ibu, bagaimana seharusnya kita secara pribadi menghadapi kemajemukan yang ada di Negara Kesatuan Republik Indonesia? (3) Menurut bapak/ibu, apa peran gereja dalam dalam merawat kemajemukan dalam bingkai Negara Kesatuan Republik Indonesia? (4) Tantangan apa yang dihadapi gereja dalam mewujudkan kemajemukan dalam bingkai Negara Kesatuan Republik Indonesia.

\section{HASIL DAN PEMBAHASAN}

Kemajemukan merupakan sebuah karunia yang Tuhan berikan kepada bangsa Indonesia. Kemajemukan berasal dari kata dasar majemuk yang berdasarkan Kamus Besar Bahasa Indonesia diartikan sebagai terdiri atas beberapa bagian yang merupakan kesatuan (Badan Pengembangan dan Pembinaan Bahasa, 2016). Kemajemukan Indonesia terdiri dari kemajemukan suku, agama, ras, golongan, berbeda etnis, budaya, bahasa daerah yang tersebar di 17.000 pulau besar dan kecil. Jika ditinjau dari struktur sosialnya maka kemajemukan yang ada di Indonesia berdimensi ganda artinya memiliki kemajemukan secara horizontal dan vertikal. Secara horizontal tanpa membeda-bedakan tinggi rendahnya kelas sosial, misalnya perbedaan agama, ras, etnis, budaya, pekerjaan. Sedangkan kemajemukan secara vertikal akan melahirkan stratifikasi sosial artinya masyarakat dibedakan berdasarkan kelas-kelas secara bertingkat, yaitu kaya-miskin, penguasa-rakyat jelata (Pursika, 2009).

Kemajemukan di Indonesia tidak selalu menciptakan keindahan, keunikan dan beberapa hal positif lainnya. Kemajemukan tersebut juga dapat berpotensi sebagai ancaman berupa perpecahan antar kelompok, kecemburuan sosial, konflik agama, konflik suku (Hikmawaty, 2014). Konflik yang terjadi di Indonesia sebenarnya bukan karena adanya kemajemukan tersebut tetapi diakibatkan kesalahpahaman dari komunikasi. Oleh karenanya dituntut untuk saling menghargai, saling menghormati setiap perbedaan yang ada. 
Kemajemukan yang ada di bangsa Indonesia disatukan dalam sebuah semboyan Bhinneka Tunggal Ika yang diambil dari kitab Sutasoma karangan Mpu Tantular yang artinya beraneka ragam, berbeda-beda tetapi satu (unity in diversity). Itu berarti sekalipun bangsa Indonesia berbeda dalam suku, agama, ras, budaya, bahasa daerah tetapi menjadi satu dalam bingkai Negara Kesatuan Republik Indonesia. Hendaknya dipahami bahwa kesatuan bukan tentang keseragaman, tetapi kesatuan berbicara tentang kebersamaan dalam keragaman.

Sekali pun ada perbedaan, namun hal tersebut menjadi sebuah kekhasan atau keunikan bangsa Indonesia, perbedaan merupakan kekayaan bangsa yang harus disyukuri, perbedaan merupakan aset yang berharga bagi bangsa Indonesia, perbedaan bukanlah perpecahan tetapi kekuatan bangsa.

Berdasarkan temuan data primer yang peneliti dapatkan seperti: (1) kemajemukan adalah anugerah dari Tuhan yang berguna untuk saling melengkapi, oleh karenanya jemaat harus bersyukur dengan adanya perbedaan tersebut; (2) Mensyukuri perbedaan tersebut dan menjadikannya kesempatan untuk saling bekerja sama sekalipun terdapat banyak perbedaan; (3) Gereja harus menunjukkan sikap toleransi, menunjukkan sikap saling mengasihi; gereja mengusahakan terjadinya dialog lintas agama dan keyakinan untuk menjembatani perbedaan di tengah-tengah masyarakat; (4) tantangan gereja adalah adanya sekelompok orang yang memiliki wawasan sempit sehingga menimbulkan intoleransi bahkan radikalisme, maka peran gereja dalam merawat kemajemukan di Indonesia dapat diuraikan dalam beberapa point di bawah ini.

\section{Membangun Kerjasama}

Gereja merupakan bagian integral dari bangsa ini. Hal ini tidak dapat diragukan lagi. Pernyataan ini telah disampaikan secara berulang-ulang baik oleh orang Kristen maupun pemimpin bangsa ini (Yewangoe, 2011). Sejarah membuktikan bahwa orang Kristen telah terlibat dalam banyak kesempatan bersejarah di bangsa Indonesia. Misalnya saja, penulis lagu kebangsaan Indonesia W.R. Supratman, dan tentunya banyak tokoh-tokoh lainnya baik pejuang kemerdekaan, tokoh politik dan tokoh publik lainnya. Para pendahulu ini bekerja sama tanpa memandang agama, suku, ras, golongan untuk membebaskan Indonesia dan penjajahan bangsa asing dan untuk mengisi kemerdekaan yang telah direbut. 
Santinus (2021) mengungkapkan sebagai bagian integral dari bangsa, maka gereja membuka peluang untuk bekerja sama dengan semua komponen masyarakat sekali pun terdapat banyak perbedaan. Kerja sama ini bertujuan untuk mewujudkan keadilan sosial bagi seluruh rakyat idonesia (Santinus, 2021). Beberapa contoh konkrit yang bisa dilakukan oleh gereja diantaranya: kerja sama membersihkan saluran pembuangan air (got) dari sampah-sampah yang menghambat, membangun rumah ibadah baik masjid, pura, vihara, dan rumah ibadah agama lainnya, membantu tetangga atau masyarakat yang ditimpa kemalangan, bekerja sama membangun jalan, kerja sama menjaga keamanan lingkungan (siskamling), pengamanan acara-acara keagamaan, dan banyak contoh kerja sama yang lainnya. Kerja sama yang demikian akan menjadikan masyarakat solid dan hubungan kekeluargaan akan terjalin dengan erat, akan menimbulkan rasa saling memiliki dan saling membutuhkan, terciptanya keharmonisan di tengah masyarakat. Dengan demikian maka sekat-sekat pemisah dengan sendirinya menjadi hilang karena semua warga masyarakat yang berbeda suku, agama dan kepercayaan terbentuk menjadi satu keluarga yang saling memedulikan. Oleh karena itu, diharapkan gereja sebagai garam dan terang dunia menjadi inisiator kerja sama di lingkungan masyarakat.

\section{Sikap Toleransi}

Sebagaimana diuraikan di atas bahwa kemajemukan merupakan karunia yang harus disyukuri oleh setiap anak bangsa. Dalam kemajemukan tersebut maka setiap komponen bangsa harus saling menghargai setiap perbedaan yang ada, baik perbedaan agama, budaya, suku, ras dan perbedaan golongan. Gereja sebagai bagian dari anak bangsa menjaga kemajemukan tersebut dengan menunjukkan sikap toleransi. Toleransi antar umat beragama merupakan sebuah mekanisme sosial sebagai upaya untuk menyikapi perbedaan (Faridah, 2013). Toleransi antar umat beragama tidak dimaksudkan untuk mengakui kebenaran semua agama, melainkan keteguhan hati pada kebenaran yang diyakininya dan tidak menganggap bahwa ajaran agama lain salah (Casram, 2016).

Sikap toleransi merupakan hal yang fundamental untuk diterapkan dalam menyikapi kemajemukan di tengah-tengah masyarakat. Hal ini senada dengan pernyataan dari Muhammad Luthfi bin Yahya bahwa peran toleransi merupakan hal 
yang paling fundamental dalam merawat kebhinekaan (Hasan, 2021). Dengan menjunjung sikap toleransi maka perbedaan bukan lagi menjadi momok yang menakutkan, sebaliknya menjadi kesempatan untuk saling bertukar inspirasi, aspirasi guna mengejar ketertinggalan bangsa Indonesia dari bangsa-bangsa lain yang lebih dulu disebut sebagai negara maju.

Menghargai perbedaan sebagai upaya menjaga keutuhan bangsa dalam bingkai negara kesatuan republik Indonesia merupakan panggilan yang harus dikerjakan oleh orang percaya. Mengutip pendapat Ali bin Abi Thalib yang berkata, "mereka yang tidak saudara dalam iman, adalah saudara dalam kemanusiaan (ukhuwah basyariyah)," hal ini ditegaskan oleh H. Yaqut Cholil Qoumas ketika ditunjuk sebagai Menteri Agama Republik Indonesia (Mawardi, 2020). Bahkan Alkitab lebih tegas mengingatkan untuk menunjukkan kasih kepada sesama manusia sebagaimana kepada diri sendiri (Im. 19:18; Mat. 22:39). Bahkan kepada orang yang memusuhi, Tuhan Yesus memberi perintah untuk berdoa dan memberkati mereka. Semangat inilah kiranya yang menjadi nafas gereja dalam membangun hubungan masyarakat di tengah kemajemukan bangsa Indonesia.

Di tengah maraknya sikap intoleransi, firman Tuhan mengajarkan untuk hidup berdamai dengan semua orang (band. Ibr. 12:14). Merujuk kepada kebenaran tersebut maka orang Kristen diharapkan untuk menjaga situasi harmonis dan kondusif di semua komunitas di mana mereka boleh hadir. Hal tersebut senada dengan yang disampaikan oleh Novalina, "di tengah semakin berkembangnya sikap intoleransi yang terjadi di Indonesia, semua pihak harus mengupayakan kerukunan dan keharmonisan dalam beragama" (Novalina et al., 2021). Gereja tidak boleh reaktif dengan melakukan hal yang melanggar hukum yang pada akhirnya menimbulkan kekisruhan yang semakin besar.

Menyikapi kelompok-kelompok intoleran, maka gereja sebaiknya menyerahkan permasalahan tersebut kepada arat penegak hukum untuk memproses sesuai dengan hukum yang berlaku di Negara Kesatuan Republik Indonesia. Santinus menekankan supaya pendeta dan pengajar Kristen menyuarakan hal tersebut dalam khotbah di mimbar gereja maupun dalam kelas-kelas pengajaran sehingga jemaat mendapat arahan yang sama untuk menjaga sikap toleransi di tengah kemajemukan bangsa (Santinus, 
2021). Hal yang sama berlaku bagi gereja yang menjadi kelompok minoritas maupun sebagai kelompok mayoritas di suatu daerah tertentu.

Hendaknya tidak ada warga gereja yang bertindak di luar arahan dari pemimpin gereja. Di sinode Gereja Suara Kebenaran Injil, gembala Sinode Erastus Sabdono selalu mengingatkan jemaat untuk memilih sikap diam dan tidak bereaksi atas orangorang yang menujukkan sikap intoleran, melakukan persekusi atas nama agama, melakukan tekanan terhadap kelompok yang lain (Sabdono, 2020). Hal ini ditunjukkan dalam teladan hidup yang dapat dijadikan sebagai panutan bagi seluruh jemaat Gereja Suara Kebenaran Injil di mana pun berada. Hal tersebut dinyatakan dengan tegas kepada seluruh pejabat gereja dan jemaat untuk mengikuti arahannya atau memiliki sikap yang berbeda disarankan untuk keluar dari sinode Gereja Suara Kebenaran Injil.

\section{Saling Mengasihi}

Firman Tuhan mengingatkan untuk mengenakan kasih sebagai tali pengikat yang mempersatukan dan menyempurnakan (Kol. 3:14). Smith Jr. (2016) menyatakan bahwa ungkapan akhir dari kesatuan dan keragaman adalah kasih yang dapat mempersatukan seluruh umat manusia (Smith Jr, 2016). Kasih akan menghilangkan rasa curiga, kasih akan membangkitkan rasa aman, kasih akan menutupi setiap kekurangan dan keterbatasan, pada akhirnya kasih akan menyatukan segala perbedaan. Yewangoe (2011) menegaskan bahwa kasih Kristus tidak dibatasi oleh suku, agama, ras, etnis dan sebagainya (Yewangoe, 2011). Dengan demikian maka tindakah kasih yang dilakukan oleh gereja tidak dibatasi oleh sekat-sekat perbedaan.

Wujud nyata dari kasih dapat ditunjukkan melalui program berbagi kasih, pengobatan massal, pembagian paket sembako, menolong janda dan anak yatim-piatu, gerakan orangtua asuh, menolong korban bencana alam, dan bentuk-bentuk pelayanan sosial lainnya. Mimbar gereja hendaknya dipakai juga untuk mengajar jemaat menjadi teladan di tengah-tengah masyarakat melalui program-program nyata yang dapat dirasakan oleh masyarkat sekitar (V. Simanjuntak, 2021). Kehadiran gereja di tengahtengah masyarakat dapat dirasakan oleh masyarakat. Kehadiran gereja dapat diterima oleh masyarat yang multi-religi melalui program-program yang dilakukan oleh gereja. Gereja tidak menjadi komunitas yang egois yang hanya peduli terhadap umat di dalam tembok gereja saja tetapi menjadi gereja yang peduli bahkan menjadi inisiator setiap 
kebaikan-kebaikan yang terjadi di lingkungan masyarakat. Berkhof dalam Yewangoe berkata bahwa "pelayanan kasih menyelaraskan pelayanan firman dengan perbuatan nyata sehingga keselamatan yang diterima bukan hanya sebuah wacana tetapi sebuah kekuatan yang dapat mengubahkan" (Yewangoe, 2011). Tindakan kasih tidak saja mengubahkan warga gereja sebagai objek pemberitaan firman, tetapi mengubahkan warga masyarakat. Mengubah kebencian menjadi kasih, mengubah penolakan menjadi penerimaan, mengubah permusuhan menjadi persahabatan.

Gereja Suara Kebenaran Injil dikenal luas bukan hanya penekanan dalam pengajaran yang menekankan kesucian hidup yaitu kesempurnaan seperti Bapa dan keserupaan dengan Yesus -di mana dalam setiap pikiran, perasaan dan kehendaknya selalu sesuai dengan pikiran dan perasaan Bapa- fokus hidup yang dipindahkan dari kesementaraan kepada langit baru bumi baru, dan sikap hidup yang bertanggung jawab. Gereja Suara Kebenaran Injil juga dikenal karena aksi-aksi nyata untuk menolong sesama. Dalam banyak kesempatan sinode Gereja Suara Kebenaran Injil menolong masyarakat yang terdampak bencana alam, diantaranya memberikan bantuan bagi korban banjir di Jakarta dan Banten (2020), memberikan ribuan paket bantuan kepada korban badai Siklon Seroja di Nusa Tenggara Timur tahun 2021 (Timu, 2021). Meniru teladan dari ketua Sinode Gereja Suara Kebenaran Injil maka gereja lokal yang ada di Medan juga melakukan hal yang sama di mana sejak 2018 secara rutin memberikan bantuan paket sembako kepada masyarakat, memberikan paket obat-obatan dan vitamin bagi penderita Covid-19 (2021), menjadi orangtua asuh bagi siswa miskin. Bantuan-bantuan tersebut diberikan tanpa membedakan suku, agama dan kepercayaan. Pemberian bantuan-bantuan tersebut adalah wujud kasih yang telah ditunjukkan oleh Yesus bagi jemaat Gereja Suara Kebenaran Injil.

\section{Dialog Lintas Agama}

Tidak bisa dinafikan bahwa perbedaan-perbedaan yang ada di tengah masyarakat, khususnya perbedaan agama dan keyakinan dapat bertumbuh menjadi radikal sehingga menimbulkan konflik di tengah-tengah masyarakat. Konflik antar agama selalu mewarnai perjalanan bangsa ini dalam beberapa tahun belakangan ini. Beberapa di antaranya adalah konflik di Ambon, Maluku tahun 1999 (Boedi, 2016), peristiwa bom Bali tahun 2002 (S. Y. Simanjuntak, 2016), konflik berkepanjangan GKI 
Yasmin di Bogor (Setiono, 2012), konflik berkepanjangan HKBP Pondok Timur Indah Ciketing, Bekasi (Wiliam, 2015), perusakan dan pembakaran gereja-gereja di Aceh Singkil tahun 2005 yang justeru dipasilitasi oleh pemerintah daerah (Tempo, 2015), pembakaran klenteng di Kota Tanjung Balai, Sumatera Utara tahun 2016 (Syahputra, 2018), kasus penodaan agama oleh gubernur Basuki Tjahaja Purnama tahun 2017 (Tempo, 2017), dan tentunya banyak konflik bernuansa SARA lainnya. Konflik horizontal seperti ini telah menimbulkan ketidaknyamanan di tengah masyarakat dan melahirkan kecurigaan kepada pemeluk agama lain. Jika konflik yang mengatasnamakan agama tidak segera diselesaikan dengan baik akan berakibat kepada disintegrasi bangsa.

Salah satu upaya yang dapat dilakukan untuk mengatasi konflik horizontal yang timbul di tengah-tengah masyarakat adalah melalui dialog-dialog lintas agama (Damanik, 2021). Anwar (2018) menguraikan bahwa dialog lintas agama bertujuan agar: pertama, pemeluk agama bisa hidup berdampingan dengan damai, rukun, aman, saling menghargai dan saling menghormati. Kedua, menumbuhkan rasa percaya akan iman dan pengajaran yang diamalkan setiap agama. Ketiga, membantu untuk meningkatkan kerja sama di antara masyarakat sehingga dalam saling menghargai, keadilan, perdamaian dan kerja sama yang bersahabat untuk membangun negeri (Anwar, 2018). Dialog bukanlah sebagai media menyebarkan agama, atau memaksa orang berpindah keyakinan. Dialog bukan juga sebagai media menyudutkan agama lain dan menganggap agama sendiri lebih baik. Dialog adalah sebagai kesempatan untuk melihat keunikan ajaran agama masing-masing (Novalina et al., 2021). Kerukunan dapat diperkuat melalui empat macam dialog: pertama, dialog kehidupan atau dialog persaudaraan, dialog ini dibangun dalam semangat persaudaraan yang rukun, semangat solidaritas dan subsidiaritas untuk saling peduli dan mendukung dalam hidup bersama; kedua, dialog karya atau kerja sama, dialog ini digagas oleh penganut agama yang berbeda bekerja sama dalam berbagai level lokal, nasional, dan internasional untuk menolong masyarakat yang mengalami bencana atau pun orang-orang yang mengalami kejahatan; ketiga, dialog pandangan teologis untuk para ahli yang bertujuan untuk menyampaikan warisan ajaran dan kebenaran ajaran untuk menghadapi persoalan manusia; keempat, dialog pengalaman keagamaan atau pengalaman iman untuk memperkaya dan memajukan penghayatan nilai-nilai dan cita-cita rohani masing- 
masing agama (Akoit, 2019). Oleh sebab itu pemimpin gereja dapat menginisiasi adanya dialog-dialog lintas agama.

\section{SIMPULAN}

Berdasarkan uraian penelitian di atas dapat disimpulkan bahwa Gereja Suara Kebenaran Injil di Kota Medan sudah cukup berperan dalam mengupayakan kemajemukan yang ada di Indonesia. Hal ini terlihat dari jawaban yang diberikan responden. Menurut mereka, gereja sangat perlu hadir di tengah masyarakat sebagai solusi bagi permasalahan bangsa. Kehadiran Gereja Suara Kebenaran Injil di tengahtengah masyarakat diwujudkan melalui upaya membangun kerja sama dengan semua komponen masyarakat yang ada, itu berarti kerja sama yang dibangun tidak dibatasi oleh sekat-sekat perbedaan suku, agama, ras, dan banyak perbedaan lainnya yang merupakan ciri khas bangsa Indonesia. Meneladani sikap gembala sinode Gereja Suara Kebenaran Injil maka Gereja Suara Kebenaran Injil di Kota Medan memandang bahwa sikap toleransi sebagai upaya untuk menjaga kerukunan dan keharmonisan dalam beragama. Mengutamakan kasih akan sesama diwujudkan melalui berbagai program yang dapat menyentuh semua masyarakat. Kehadiran gereja harus dapat dirasakan oleh masyarakat di sekitarnya. Mengupayakan dialog sebagai upaya menjembatani kebuntuan di tengah masyarakat sebagai upaya untuk merawat kemajemukan dalam bingkai Negara Kesatuan Republik Indonesia.

\section{DAFTAR PUSTAKA}

Akoit, Y. (2019). Memperkuat Kerukunan Melalui Dialog. Https:/Ntt.Kemenag.Go.Id/Berita/510490/Memperkuat-Kerukunan-MelaluiDialog

Anwar, M. K. (2018). Dialog Antar Umat Beragama Di Indonesia: Perspektif A. Mukti Ali. Jurnal Dakwah, 19(1), 89-107.

Https://Core.Ac.Uk/Display/230869599?Utm_Source=Pdf\&Utm_Medium=Banner \&Utm_Campaign=Pdf-Decoration-V1

Aritonang, A. (2019). Peran Sosiologis Gereja Dalam Relasi Kehidupan Antar Umat Beragama Indonesia. TE DEUM (Jurnal Teologi Dan Pengembangan Pelayanan), 9(1), 69-102. Https://Doi.Org/10.51828/Td.V9i1.9

Aziz, M. (2017). Merawat Kebinekaan. Gramedia.

Badan Pengembangan Dan Pembinaan Bahasa. (2016). Majemuk. KBBI Online. Https://Kbbi.Kemdikbud.Go.Id/Entri/Majemuk

Batubara, H. (2019). PGI Sumut Tanggapi Kasus Penghadangan Beribadah Jemaat 
GBI Philadelpia. Https:/News.Detik.Com/Berita/D-4386173/Pgi-Sumut-

Tanggapi-Kasus-Penghadangan-Beribadah-Jemaat-Gbi-Philadelpia

Boedi, T. S. (2016). Resolusi Konflik Agama Di Pulau Ambon. Jurnal Ketahanan

Nasional, 14(3), 51-60. Https://Doi.Org/10.22146/JKN.22305

Casram, C. (2016). Membangun Sikap Toleransi Beragama Dalam Masyarakat Plural.

Wawasan: Jurnal Ilmiah Agama Dan Sosial Budaya, 1(2), 187-198.

Https://Doi.Org/10.15575/Jw.V1i2.588

Cipta, S. E. (2020). 100\% KATOLIK 100\% INDONESIA: Suatu Tinjauan Historis

Perkembangan Nasionalisme Umat Katolik Di Indonesia. Jurnal Sosiologi Agama,

14(1), 175. Https://Doi.Org/10.14421/Jsa.2020.141-07

Damanik, J. F. (2021). Menurut Bapak/Ibu, Apa Peran Gereja Dalam Dalam Merawat Kemajemukan Dalam Bingkai Negara Kesatuan Republik Indonesia?

Erlangga, Y. (2017). Ayo! Merawat Indonesia. Esensi.

Faridah, I. F. (2013). Toleransi Antarumat Beragama Masyarakat Perumahan.

Komunitas: International Journal Of Indonesian Society And Culture, 5(1).

Https://Doi.Org/10.15294/Komunitas.V5i1.2368

Hasan, A. H. (2021). Habib Luthfi Bin Yahya Ungkap Peran Toleransi Dalam Merawat Kebhinekaan. Https://Jabar.Nu.Or.Id/Detail/Habib-Luthfi-Bin-Yahya-Ungkap-

Peran-Toleransi-Dalam-Merawat-Kebhinekaan-

Hikmawaty, L. (2014). Penerapan Model Pembelajaran Kritik Tari Untuk

Meningkatkan Pemahaman Multikultur Siswa Kelas XI SMA Negeri 7 Tangerang.

Universitas Pendidikan Indonesia.

Http://Repository.Upi.Edu/11968/4/T_PSN_1201350_Chapter1.Pdf

Lidwina, A. (2021). Intoleransi, Pelanggaran Kebebasan Beragama Terbanyak

Dilakukan Aktor Non-Negara. Databoks.Katadata.Co.Id, April, 2021.

Https://Databoks.Katadata.Co.Id/Datapublish/2021/04/09/Intoleransi-Pelanggaran-

Kebebasan-Beragama-Terbanyak-Dilakukan-Aktor-Non-Negara

Mawardi, M. (2020). Kutip Kalimat Ali Bin Abi Thalib, Gus Yaqut: Mereka Yang Tidak Saudara Dalam Iman, Adalah Saudara Dalam Kemanusiaan.

Https://Halosemarang.Id/Kutip-Kalimat-Ali-Bin-Abi-Thalib-Gus-Yaqut-Mereka-

Yang-Tidak-Saudara-Dalam-Iman-Adalah-Saudara-Dalam-Kemanusiaan

Muslim. (2021). 5 Pernyataan Muhammad Kace Yang Dianggap Menghina Agama Islam. Https://Jurnalmedan.Pikiran-Rakyat.Com/Nasional/Pr-1492451840/5Pernyataan-Muhammad-Kace-Yang-Dianggap-Menghina-Agama-Islam

Novalina, M. (2020). Spiritualitas Orang Kristen Dalam Menghadirkan Kerajaan Allah

Di Tengah Tantangan Radikalisme. Jurnal Teologi Kontekstual Indonesia, 1(1),

26. Https://Doi.Org/10.46445/Jtki.V1i1.293

Novalina, M., Nixon, G., Sabdono, E., Eli Zaluchu, S., \& Christabella Phuanerys, E.

(2021). Nostra Aetate: Sebuah Alternatif Menuju Keharmonisan Di Tengah

Suburnya Intoleransi Dan Diskriminasi. KURIOS, 7(2).

Https://Doi.Org/10.30995/Kur.V7i2.340

Peter, R. (2020). Pendidikan Agama Kristen Dalam Membangun Wawasan Kebangsaan Menghadapi Isu Intoleransi Dan Radikalisme. Vox Dei: Jurnal Teologi Dan Pastoral, 1(2), 89-103. Https://Doi.Org/10.46408/Vxd.V1i2.13

Pieter, J., \& Titaley, J. A. (2014). Hubungan Antar Agama Dalam Kebhinekaan Indonesia. Waskita, Jurnal Studi Agama Dan Masyarakat, 2(2), 19-47.

Https://Ejournal.Uksw.Edu/Waskita/Article/View/157

Pursika, I. N. (2009). Kajian Analitik Terhadap Semboyan "Bhinneka Tunggal Ika". 
Jurnal Pendidikan Dan Pengajaran, 42(1), 15-20.

Https://Doi.Org/10.23887/JPPUNDIKSHA.V42I1

Putranto, W. G. (2021). Jozeph Paul Zhang Diduga Hina Islam, Muannas Alaidid: Demi Allah Saya Akan Kejar Anda. Tribunnews.

Https://Www.Tribunnews.Com/Nasional/2021/04/18/Jozeph-Paul-Zhang-Diduga-

Hina-Islam-Muannas-Alaidid-Demi-Alllah-Saya-Akan-Kejar-Anda?Page=3

Sabdono, E. (2020). DIAM ITU EMAS. Truth.Id. Https://Youtu.Be/Dv17N0bwuj4

Santinus, M. (2021). Menurut Bapak/Ibu, Apa Peran Gereja Dalam Dalam Merawat

Kemajemukan Dalam Bingkai Negara Kesatuan Republik Indonesia?

Setiono, G. D. (2012). Pemberitaan Konflik GKI Yasmin Bogor Pada Harian Jurnal

Bogor Dan Radar Bogor. Ejurnal Mahasiswa Universitas Padjadjaran Vol.1., No.1

(2012), 1(1), 1-10. Https://Jurnal.Unpad.Ac.Id/Ejournal/Article/View/1095

Simanjuntak, S. Y. (2016). Analisis Kerja Sama Bilateral Indonesia Dengan Australia

Dalam Penanggulangan Terorisme Sebagai Kejahatan Transnasional Terorganisir

(2002-2015). Journal Of International Relations, 2(3), 117-127. Http://Ejournal-

S1.Undip.Ac.Id/Index.Php/Jihiwebsite:Http://Www.Fisip.Undip.Ac.Id

Simanjuntak, V. (2021). Menurut Bapak/Ibu, Apa Peran Gereja Dalam Dalam

Merawat Kemajemukan Dalam Bingkai Negara Kesatuan Republik Indonesia?

Siswoyo, H., \& Nasution, S. P. (2016). Menilik Kasus Intoleransi Di Tanjungbalai.

Https:/Www.Viva.Co.Id/Ragam/Fokus/803199-Menilik-Kasus-Intoleransi-Di-

Tanjungbalai

Smith Jr, A. T. (2016). The Unity And Diversity Of The Christianfaith. In Dalam Satu Roh Berbagi Karunia Merawat Keutuhan (P. 323). STT Cipanas.

Syahputra, I. (2018). Penggunaan Media Sosial Dan Kemarahan Religius Dalam Kasus

Pembakaran Vihara Di Kota Tanjung Balai, Indonesia. Epistemé: Jurnal

Pengembangan Ilmu Keislaman, 13(1).

Https://Doi.Org/10.21274/Epis.2018.13.1.149-172

Tempo. (2015). Gereja Dibakar Di Aceh Singkil, Inilah Dugaan Penyebabnya.

Https://Nasional.Tempo.Co/Read/709143/Gereja-Dibakar-Di-Aceh-Singkil-Inilah-

Dugaan-Penyebabnya

Tempo. (2017). Kasus Penodaan Agama, Ahok Divonis 2 Tahun Penjara.

Https://Nasional.Tempo.Co/Read/873597/Kasus-Penodaan-Agama-Ahok-Divonis-

2-Tahun-Penjara

Timu, D. (2021). Sinode GSKI Terus Salurkan Bantuan Untuk Gereja-Gereja Yang

Rusak Akibat Badai Seroja Di Rote Ndao. Https://Www.Portalntt.Com/Sinode-

Gski-Terus-Salurkan-Bantuan-Untuk-Gereja-Gereja-Yang-Rusak-Akibat-Badai-

Seroja-Di-Rote-Ndao/

Utomo, P. (2019). Fakta Di Balik Penggerudukan Tempat Ibadah Di Kota Medan.

Https:/Www.Jawapos.Com/Jpg-Today/14/01/2019/Fakta-Dibalik-Penggerudukan-

Tempat-Ibadah-Di-Kota-Medan/

Wiliam, G. (2015). Analisa Manajemen Dan Resolusi Konflik Agama: Studi Kasus

HKBP (Huria Kristen Batak Protestan) Pondok Timur Indah, Kota Bekasi Tahun 2010-2014.

Http://Portalgaruda.Fti.Unissula.Ac.Id/Index.Php?Ref=Browse\&Mod=Viewarticle \&Article $=357521$

Yewangoe, A. A. (2011). Tidak Ada Penumpang Gelap: Warga Gereja, Warga Bangsa. BPK Gunung Mulia.

Zaluchu, S. E. (2020). Strategi Penelitian Kualitatif Dan Kuantitatif Di Dalam 
Penelitian Agama. Evangelikal: Jurnal Teologi Injili Dan Pembinaan Warga Jemaat, 4(1), 28. Https://Doi.Org/10.46445/Ejti.V4i1.167 